\title{
MEASURING OCCUPATIONAL HEALTH AND SAFETY VULNERABILITY AMONG HOSPITAL NURSES \\ IN DR.SARDJITO HOSPITALYOGYAKARTA
}

\author{
Desrifana Yunus
}

\author{
Universitas Gadjah Mada
}

\begin{abstract}
Background: Nurses are health workers who have risks and vulnerable with workplace accidents. Occupational accidents and cccupational disease per 100 workers in hospitals are almost double compared to the private sector and higher compared to the mining, manufacturing, and construction sectors. Occupational health and safety (OH\&S) vulnerability defines as exposed to hazards and classified as having inadequate access to one of the three kinds of mitigation resources. The three mitigation resources are policy and procedure, awareness, and empowerment. The purpose of this study was to measuring OH\&S vulnerability among hospital nurses, Yogyakarta.

Subjects and Method: This was a quantitative descriptive conducted in Yogyakarta. A total of 30 nurses was selected for this study. The dependent variable was OH\&S vulnerability in 3 areas: policy and procedure, awareness, and empowerment. The data were collected by questionnaire and in-depth interview. The data were analyzed descriptively.

Results: Three types of OH\&S vulnerability were exposed to hazards, including: policy and procedure, awareness, and empowerment. $90.00 \%$ of nurses in the hospital were exposed to hazards, such as working with awkward posture and exposure to dangerous gas. $10.00 \%$ of the sample had no adequate access to $\mathrm{OH} \& \mathrm{~S}$ policy and procedure at workplace. $16.70 \%$ of nurses were lack of awareness of workplace rights and responsibility. $33.30 \%$ of nurses had inadequate $\mathrm{OH} \& \mathrm{~S}$ empowerment. $50.00 \%$ of nurses was vulnerable to workplace illness or injury

Conclusion: Most of the nurses have vulnerability to occupational health and safety. It is necessary to increase access to OH\&S policies and procedures, awareness and empowerment
\end{abstract}

Keywords: occupational health, safety, vulnerability, hazard, nurse, hospital

\section{Correspondence:}

Desrifana Yunus. Universitas Gadjah Mada, Yogyakarta. Email: desrifana@gmail.com. Mobile: 081299024990 